\title{
The Effect of Synthetic Phonics on ESL Pupils' Phonological Awareness
}

\author{
Yvonne Asong Anthony, Nur Ehsan Mohd Said
}

\begin{abstract}
The development of basic literacy skills is so essential that it begins even before a child enters formal schooling. In Malaysia, the English Language Literacy skill is very crucial that the Ministry of Education implemented the new curriculum, Standardised Curriculum for Primary Schools, which mainly focuses on developing reading through phonics. In recent years, phonological awareness has been given great attention. This study aims to examine the impact of synthetic phonics on English as Second Language (ESL) learners' phonological awareness. This research describes an action research project that employed Jolly Phonics strategy implemented as a classroom intervention. The research involving 20 ESL learners aged 7 years old who attended a primary school in a rural area in Julau, Sarawak. The research instrument adapted was Kaminski (2002) Dynamic Indicators of Early Literacy (DIBELSTM) through a pre-test-and post-test design. The data obtained were analysed by using a descriptive method such as frequency calculations and percentages were calculated in the form of scores. The findings revealed the pupils increased their oral reading ability after being taught through phonics. The studies implied this systematic strategy could be useful in developing phonological awareness among learners to become successful readers.
\end{abstract}

Index Terms - ESL, Jolly Phonics, Phonological Awareness, Primary, Synthetic Phonics

\section{INTRODUCTION}

In the research on reading skill, it is proven that phonological awareness has been given much attention lately. This is due to most critical levels of phonological awareness can be developed through carefully planned instruction. This development impacted notably on children's reading and spelling achievement (O'Connor \& Padeliadu, 2000). Nevertheless of the encouraging result, yet many questions and misconception about phonological awareness remain unanswered. As for instance, the researchers are looking for ways to determine how much and what type of instruction is necessary and for whom. Besides, many people do not understand the difference between phonological awareness, phonemic awareness, and phonics. In addition, others are unsure about the relationship between phonological awareness and early reading.

In Malaysia, phonological awareness has been in the spotlight since the introduction of a Literacy Intervention Programme, (LBI) 2.0. The programme was introduced by the

Yvonne Asong Anthony, Student at Faculty of Education, Universiti Kebangsaan Malaysia (UKM) 43600, Bangi, Selangor, Malaysia

Nur Ehsan Mohd Said, Lecturer at Faculty of Education National University of Malaysia (UKM) 43600, Bangi, Selangor, Malaysia
Ministry of Education in all Malaysian lower primary schools since the beginning of 2013 mainly for level one pupils (age between 7 to 9 years old). This initiative aims at enhancing the rate of literacy in English among the lower primary learners. Despite this emphasis, some children without learning disabilities are still unable to acquire the basic literacy skills of English during their lower primary school level.

The teaching of phonics is still very new in Malaysia. Only few studies have been done that focuses on the teaching of Phonics for primary learners (Nadiah, Napisah \& Mariyatunnitha, 2014). The teaching of phonics should focuses on innovations to the curriculum to enhance the whole language approach used for teaching of reading skills on the old curriculum. In order to make sure that all children become good readers, it is essential that they learn the main letter sounds and know how to blend words using those letter sounds fluently.

The researcher decided to examine the impact of synthetic phonics on English as Second Language (ESL) learners' phonological awareness specifically for struggle readers. This gap in the literature raises the question of whether phonics, and specially the synthetic phonics instruction reveals equal effects on English literacy learning regardless of the learning context and the learners. With that in mind, this research employed to investigate to what extent the Jolly Phonics affect the reading and writing on primary school pupils from an early age.

\section{LITERATURE REVIEW}

\section{A. Roles of Phonological Awareness}

The main indicator for a child to know how to read is the ability to recognise alphabet and phonemic awareness (Stanovich \& Siegle, 1994). This phonological awareness is in relation to children's early reading. Without phonemic awareness, learners may be confused by the print system and how it represents the spoken word. Morais, Mousty \& Kolinsky (1998) indicate that phonological awareness is necessary and critical for reading acquisition. Similarly, Koda (2005) highlighted that the lower level verbal processing skills, such as phonological processing, which is the product of developing phonemic awareness, is important for the process of registering information in working memory in reading. The good understanding of phonological awareness will give learners fundamental framework for reading as they are able to decode and encode phonics that they learned (Adams et al., 1998). Over the past two decades, researchers have focused primarily on 
the contribution of phonological awareness to reading acquisition. However, the relationship between phonological awareness and reading is not unidirectional but reciprocal in nature. Early reading is dependent on having some understanding of the internal structure of words, and explicit instruction in phonological awareness skills is very effective in promoting early reading. However, instruction in early reading-specifically, explicit instruction in letter-sound correspondence appears to strengthen phonological awareness (Snow, Burns, \& Griffin, 1998).

\section{B. Teaching of Phonics}

The knowledge of phonemes and graphemes should be taught because it will enable pupils to identify words in linear and non-linear texts. In a study by Yeung et all (2013), the findings suggest that phonological awareness instruction embedded in vocabulary learning activities might be beneficial to kindergarteners learning English as a second language. The explicit and systematic teaching of phonics will allow pupils to become independent reader through fun-filled activities (Abdullah, Kepol \& Shari, 2014). Equally to research by (Ding, 2015) indicated that implicit phonics instructions has a major effect mainly on low proficient ESL learners who lacks exposure to English. This is due to the implicit phonics instruction is helpful in providing phonics teaching in real reading experience.

\section{Synthetic Phonics}

According to Gray et al., (2007), synthetic phonics instruction is a systematic phonics approach involves the teaching of letter-sound relationships in an explicit, organised and sequenced manner. It is seen as a productive method for developing reading skills as it is an explicit method of teaching that exposes students to step-by-step phonics, from the teaching of individual sounds to the blending and segmenting of sounds.

According to the research, compared to unsystematic approach to teach phonics, the systematic instruction to teach phonics has been proven to give positive impact to learner's in term of their reading ability. It is evident that synthetic phonics programme can help to improve the ability to decode and identify isolated words. This is especially true for low achiever learners with reading and learning difficulties (Ferguson et al., 2011). In the same study, Khairul et al., (2015) also indicates that synthetic phonics could be effective in developing early reading skills for struggling readers.

\section{Jolly Phonics as a Synthetic Phonics in pupils' phonological awareness}

Jolly Phonics is a fun and child centred approach to teaching literacy through synthetic phonics. The synthetic multisensory approach has motivating actions for each of the 42 letter sounds of English and it also teaches five important skills for reading and writing. These five skills include (i) learning the letter sounds which consist of the alphabet sounds as well as diagraphs (e.g. sh, ai, etc.), (ii) learning letter formation, (iii) blending, (iv) segmenting, and (v) tricky words that have irregular spellings and children learn them separately in this method (Llyod et al, 1998).

\section{METHODOLOGY}

\section{A. Research Design and Procedures}

The research design utilized the quantitative approach to investigate the effect of using Jolly Phonics to participants' phonemic awareness. The design of this study is the pre-test, treatment, and post-test design. A pre-test was conducted at the beginning of the study with before the start of the treatment. The purpose of this pre-test was to determine the level of pupils' phonological awareness. The post test was administered after the treatments. Data from the pre- test and post-test were then analysed to see any difference in performance from pre to post test (gain scores). The tests utilised in this study was adapted by the researcher to suit the students' level of proficiency.

1) Phonics Teaching Plan adapting Jolly Phonic Strategy

Jolly Phonics act as a treatment that was implemented in a small group instruction. Participants were divided into small groups to facilitate individualized instruction. The researcher met with the groups every day for at least 15 to 20 minutes of guided instruction about letters and sounds. The letters that were chosen were based on letters that the participants did not know from the pre-test. The researcher followed the Literacy Intervention Programme, (LBI) 2.0. Reading and Writing curriculum that lists the order of letters and sounds should be taught. The pupils were taught according to the skills as shown in Table 1 below:

Table 1: Jolly Phonic Strategy

\begin{tabular}{|c|c|c|}
\hline & Skills & Explanation \\
\hline 1. & $\begin{array}{l}\text { Learning the letter } \\
\text { sounds }\end{array}$ & $\begin{array}{l}\text { Children are taught the } 42 \text { main } \\
\text { letter sounds. This includes } \\
\text { alphabet sounds as well as } \\
\text { digraphs such as sh, th, ai and ue. }\end{array}$ \\
\hline 2 & $\begin{array}{l}\text { Learning letter } \\
\text { formation }\end{array}$ & $\begin{array}{l}\text { Using different multi-sensory } \\
\text { methods, children learn how to } \\
\text { form and write the letters. }\end{array}$ \\
\hline 3 & Blending & $\begin{array}{l}\text { Children are taught how to blend } \\
\text { the sounds together to read and } \\
\text { write new words. }\end{array}$ \\
\hline 4 & $\begin{array}{l}\text { Identifying the } \\
\text { sounds in words } \\
\text { (Segmenting) }\end{array}$ & $\begin{array}{l}\text { Listening for the sounds in words } \\
\text { gives children the best start for } \\
\text { improving spelling. }\end{array}$ \\
\hline 5 & Tricky words & $\begin{array}{l}\text { Tricky words have irregular } \\
\text { spellings and children learn these } \\
\text { separately. }\end{array}$ \\
\hline
\end{tabular}


2) Phoneme segmentation Test adapted from Kaminski (2002) Dynamic Indicators of Early Literacy (DIBELS ${ }^{\mathrm{TM}}$ ).

The researcher adapted the tests and use it before (pre-test) and after the treatment (post-test). The instructions of the test are as follow:

1. Examiner probe is placed on the clipboard and position so that the pupils cannot see what the researcher record.

2. The researcher says the specific instruction to the pupils:

"I am going to say a word. After I say it, you tell me all the sounds in the word. So, if I say, "ham," you would say $/ \mathrm{h} / / \mathrm{a} / / \mathrm{m} /$. Let's try one. (one second pause) Tell me the sounds in "top".

\begin{tabular}{|c|c|}
\hline $\begin{array}{l}\text { Correct Response: } \\
\text { If pupils says, /t/ } \\
\text { /o/ /p/, the researcher } \\
\text { says }\end{array}$ & $\begin{array}{l}\text { Incorrect } \\
\text { Response: } \\
\text { If pupil gives any } \\
\text { other response, the } \\
\text { researcher says }\end{array}$ \\
\hline $\begin{array}{l}\text { Very good. The } \\
\text { sounds in "mop" are } \\
/ t / / o / / p / .\end{array}$ & $\begin{array}{l}\text { The sound in } \\
\text { "mop" are/t//o/ /p/. } \\
\text { Your turn. Tell me } \\
\text { the sound in "mop". }\end{array}$ \\
\hline
\end{tabular}

\section{Alright, here is your first word.}

3. Give the pupil the first word and count the time using stopwatch. If the pupil does not say a sound segment after 3 seconds, give him/her the second word and score the first word as zero segments produced.

4. As the pupils say the sound, mark the pupils response in the scoring column. Underline each different, correct, sound segment produced. Put a slash (/) through sound produced incorrectly.

5. As soon as the student is finished saying the sounds, present the next word promptly and clearly.

6. The maximum time for each sound segment is 3 seconds. If the student does not provide the next sound segment within 3 seconds, give the student the next word. If student provides the initial sound only, wait 3 seconds for elaboration.

7. At the end of 1 minute, stop presenting words and scoring further responses. Add the number of sound segments produced correctly. Record the total number of sound segments produced correctly on the bottom of the scoring sheet.

3) Pupils' results in Literacy Intervention Programme, (LBI) 2.0. Reading and Writing screening in March 2018 and October 2018

In order to know more about the impact of the intervention, the pupils' progress in the Reading and Writing screening in March and October were compared. The Reading and Writing screening were standardised throughout the country for Level One pupils aged 7 to 9 years old. The questions for reading and writing screening were divided into 12 constructs. The pupils were considered pass the screening if they were able to pass the entire 12 construct as stated in Table 2 below:
Table 2: Reading and Writing Constructs in Literacy Intervention Programme, (LBI) 2.0.

\begin{tabular}{|l|l|}
\hline Construct 1 & $\begin{array}{l}\text { :Able to identify and distinguish shape of } \\
\text { the letters of the alphabet }\end{array}$ \\
\hline Construct 2 & $\begin{array}{l}\text { :Able to associate sounds with the letters } \\
\text { of the alphabet }\end{array}$ \\
\hline Construct 3 & $\begin{array}{l}\text { :Able to blend phonemes into } \\
\text { recognizable words }\end{array}$ \\
\hline Construct 4 & :Able to segment words into phonemes \\
\hline Construct 5 & $\begin{array}{l}: \text { Able to understand and used the } \\
\text { language at word level }\end{array}$ \\
\hline Construct 6 & $\begin{array}{l}: \text { Able to participate in daily } \\
\text { conversations using appropriate phrases }\end{array}$ \\
\hline Construct 7 & $\begin{array}{l}\text { lable to understand and used the } \\
\text { labe at phrase level in liner texts }\end{array}$ \\
\hline Construct 8 & $\begin{array}{l}\text { language at phrase level in non - linear } \\
\text { texts }\end{array}$ \\
\hline Construct 9 & $\begin{array}{l}\text { :Able to read and understand sentences } \\
\text { with guidance }\end{array}$ \\
\hline Construct 10 & $\begin{array}{l}\text { :Able to understand and used the } \\
\text { language at paragraph level in non - } \\
\text { linear texts }\end{array}$ \\
\hline Construct 11 & $\begin{array}{l}: \text { Able to understand and use the language } \\
\text { at paragraph level in linear texts } \\
\text { guidance }\end{array}$ \\
\hline
\end{tabular}

\section{DATA ANALYSIS}

In this research, the instrument for data collection designed as follow:

1) Comparing the Pre-test and Post-test of DIBELS ${ }^{\mathrm{TM}}$ Phoneme Segmentation Fluency (PSF)

The PSF task is administered by the examiner orally presenting words of three to four phonemes. It requires the student to produce verbally the individual phonemes for each word. For example, the examiner says, "sat," and the student says, " $/ \mathrm{s} / / \mathrm{a} / / \mathrm{t} /$ " to receive three possible points for the word. After the student responds, the examiner presents the next word, and the number of correct phonemes produced in one minute determines the final score. The benchmark goal is 35 to 45 correct phonemes per minute.

2) Comparing the pupils' result in Literacy Intervention Programme, (LBI) 2.0. Reading and Writing screening

For the duration of 8 months, the pupils of Year 1 sat for Literacy Intervention Programme in March and October. The result for the screening in March was used as a benchmark for pupils' level of reading readiness. The result was then being compared to the pupils' performances in October. This is to see whether there is significant difference between the pupils' performances within that 8 months period.

The study is to examine whether the Jolly Phonics approach affected the Year One pupils' phonological awareness and to what extent. The results of data analysis were presented in the following table:

1) The pupils' result on DIBELS ${ }^{\text {TM }}$ Phoneme Segmentation Fluency (PSF) 
The Effect of Synthetic Phonics on ESL Pupils' Phonological Awareness

Table 3: Pupils' result on DIBELSTM Phoneme Segmentation Fluency (PSF)

\begin{tabular}{|c|c|c|c|c|}
\hline No & Pupils & $\begin{array}{l}\text { Pre-test } \\
\text { (Score) }\end{array}$ & $\begin{array}{l}\text { Post } \\
\text { Test } \\
\text { (Score) }\end{array}$ & $\begin{array}{l}\text { Different } \\
\text { of the } \\
\text { score }\end{array}$ \\
\hline 1. & A & $10 / 45$ & $37 / 45$ & 27 \\
\hline 2. & $\mathrm{~B}$ & $8 / 45$ & $15 / 45$ & 7 \\
\hline 3. & $\mathrm{C}$ & $10 / 45$ & $38 / 45$ & 28 \\
\hline 4. & $\mathrm{D}$ & $12 / 45$ & $20 / 45$ & 8 \\
\hline 5. & $E$ & $17 / 45$ & $32 / 45$ & 15 \\
\hline 6. & $\mathrm{~F}$ & $26 / 45$ & $38 / 45$ & 12 \\
\hline 7. & $\mathrm{G}$ & $31 / 45$ & $42 / 45$ & 11 \\
\hline 8. & $\mathrm{H}$ & $11 / 45$ & $20 / 45$ & 9 \\
\hline 9. & $\mathrm{I}$ & $13 / 45$ & $31 / 45$ & 18 \\
\hline 10 & $\mathrm{~J}$ & $12 / 45$ & $33 / 45$ & 21 \\
\hline 11 & $\mathrm{~K}$ & $21 / 45$ & $41 / 45$ & 20 \\
\hline 12 & $\mathrm{~L}$ & $15 / 45$ & $39 / 45$ & 24 \\
\hline 13 & $\mathrm{M}$ & $28 / 45$ & $40 / 45$ & 12 \\
\hline 14 & $\mathrm{~N}$ & $9 / 45$ & $28 / 45$ & 19 \\
\hline 15 & $\mathrm{O}$ & $17 / 45$ & $37 / 45$ & 20 \\
\hline 16 & $\mathrm{P}$ & $11 / 45$ & $21 / 45$ & 10 \\
\hline 17 & $Q$ & $08 / 45$ & $15 / 45$ & 9 \\
\hline 18 & $\mathrm{R}$ & $09 / 45$ & $18 / 45$ & 9 \\
\hline 19 & $\mathrm{~S}$ & $12 / 45$ & $36 / 45$ & 24 \\
\hline 20 & $\mathrm{~T}$ & $13 / 45$ & $35 / 45$ & 22 \\
\hline
\end{tabular}

Table 3 shows the pupils' scores for both pre and post-test on DIBELSTM Phoneme Segmentation Fluency (PSF). Besides, the data gathered also illustrated the difference of the scores between both tests used in this study. As mentioned earlier, the respondents in this study consist of mixed ability pupils. Therefore, it was observed that none of the respondents managed to get all answers correctly in the pre-test. The highest score by one of the respondents in the pre-test was only 28 out of total score 45 . Moreover, the findings also showed that the levels of words recognition competence among the students are low as some of the students only managed to get two or three correct answers. Nevertheless, after being taught by using Jolly Phonics strategy, the students managed to achieve better scores in their post-test. 11 out of 20 students managed to score more than 35 correct answers. Although some of the pupils can only achieved four or five scores different from their pre-test, the pupils demonstrated much better scores in their post-test as compared to their pre-test. The results imply that teachers need to study students' preferences in learning as different students have a different way of learning.

Table 4: Number of pupils (Percentages)

\begin{tabular}{|c|c|c|}
\hline $\begin{array}{c}\text { Number of } \\
\text { Correct Answers }\end{array}$ & Pre-Test (\%) & $\begin{array}{c}\text { Post Test } \\
(\%)\end{array}$ \\
\hline $45 / 45$ & 0.0 & 0.0 \\
\hline $44 / 45$ & 0.0 & 0.0 \\
\hline $43 / 45$ & 0.0 & 0.0 \\
\hline $42 / 45$ & 0.0 & 5.0 \\
\hline $41 / 45$ & 0.0 & 5.0 \\
\hline $40 / 45$ & 0.0 & 5.0 \\
\hline $39 / 45$ & 0.0 & 5.0 \\
\hline
\end{tabular}

\begin{tabular}{|c|c|c|}
\hline $38 / 45$ & 0.0 & 10.0 \\
\hline $37 / 45$ & 0.0 & 10.0 \\
\hline $36 / 45$ & 0.0 & 5.0 \\
\hline $35 / 45$ & 0.0 & 5.0 \\
\hline $34 / 45$ & 0.0 & 0.0 \\
\hline $33 / 45$ & 0.0 & 5.0 \\
\hline $32 / 45$ & 0.0 & 5.0 \\
\hline $31 / 45$ & 5.0 & 5.0 \\
\hline $30 / 45$ & 0.0 & 0.0 \\
\hline $29 / 45$ & 0.0 & 0.0 \\
\hline $28 / 45$ & 5.0 & 5.0 \\
\hline $27 / 45$ & 0.0 & 0.0 \\
\hline $26 / 45$ & 5.0 & 0.0 \\
\hline $25 / 45$ & 0.0 & 0.0 \\
\hline $24 / 45$ & 0.0 & 0.0 \\
\hline $23 / 45$ & 0.0 & 0.0 \\
\hline $22 / 45$ & 0.0 & 0.0 \\
\hline $21 / 45$ & 5.0 & 5.0 \\
\hline $20 / 45$ & 0.0 & 10.0 \\
\hline $19 / 45$ & 0.0 & 0.0 \\
\hline $18 / 45$ & 0.0 & 5.0 \\
\hline $17 / 45$ & 10.0 & 0.0 \\
\hline $16 / 45$ & 0.0 & 0.0 \\
\hline $15 / 45$ & 5.0 & 10.0 \\
\hline $14 / 45$ & 0.0 & 0.0 \\
\hline $13 / 45$ & 10.0 & 0.0 \\
\hline $12 / 45$ & 15.0 & 0.0 \\
\hline $11 / 45$ & 10.0 & 0.0 \\
\hline $10 / 45$ & 10.0 & 0.0 \\
\hline $9 / 45$ & 10.0 & 0.0 \\
\hline $8 / 45$ & 10.0 & 0.0 \\
\hline $7 / 45$ & 0.0 & 0.0 \\
\hline $6 / 45$ & 0.0 & 0.0 \\
\hline $5 / 45$ & 0.0 & 0.0 \\
\hline $4 / 45$ & 0.0 & 0.0 \\
\hline $3 / 45$ & 0.0 & 0.0 \\
\hline $2 / 45$ & 0.0 & 0.0 \\
\hline $1 / 45$ & 0.0 & 0.0 \\
\hline $0 / 45$ & 0.0 & 0.0 \\
\hline
\end{tabular}

Table 4 shows the number of students who scored correct answers in percentages count. The researcher adapted and monitored the tests orally presenting words of three to four phonemes. It requires the pupil to produce verbally the individual phonemes for each word. The pupils were tested individually by the teacher. Based on the results above, in the pre-test, none of the students manage to score above 35 correct answers. Only $15 \%$ of the students managed to score above 25 correct answers. However, in post-test, the number of students who scored above 25 correct answers increased to $70 \%$ compared to $15 \%$ in the pre-test. In addition, $68 \%$ of students scored below 25 correct answers in pre-test. The number of students scored below 25 correct answers in post-test decreased to $30 \%$. According to Table 4 , the test showed a significant difference between the percentages of two tests. This study finds that Jolly phonics did have a positive result on pupils' recognition of the 42 phonemes in English and it instilled confidence in them to read, sound out 
and decode words in English. Jolly Phonics which is synthetic multisensory approach supported participants' ability to discern, decode and identify key relationships in learning to read in English. This study finds that Jolly phonics was one of the factors that contributed to pupils' increased ability to read in English. Jolly phonics provided participants with a systematic means to begin their English study and develop confidence with using them. Initially, the participants struggled to make connections with the meta-language of Jolly Phonics (phoneme, grapheme, consonants, vowels, digraph and tri graph) and to connect these with their reading. However, after this initial period (stage one) the Jolly Phonics system proved beneficial as once the student mastered the meta-language they were, propelled forward faster in their reading. It was evidently visible that using the Jolly Phonics had considerable influence in improving the learner's reading ability.

2) The pupils' result on Reading and Writing Screening Literacy Intervention Programme (LBI)

Table 5: Pupils' result on Reading and Writing Screening Literacy Intervention Programme (LBI)

\begin{tabular}{|l|c|c|c|c|}
\hline No & Pupils & $\begin{array}{l}\text { March } \\
\mathbf{2 0 1 8} \\
\text { (Construct) }\end{array}$ & $\begin{array}{l}\text { October } \\
\mathbf{2 0 1 8} \\
\text { (Construct) }\end{array}$ & $\begin{array}{l}\text { Increase in } \\
\text { construct }\end{array}$ \\
\hline 1. & $\mathrm{~A}$ & $3 / 12$ & $9 / 12$ & 6 \\
\hline 2. & $\mathrm{~B}$ & $2 / 12$ & $4 / 12$ & 2 \\
\hline 3. & $\mathrm{C}$ & $2 / 12$ & $9 / 12$ & 7 \\
\hline 4. & $\mathrm{D}$ & $2 / 12$ & $6 / 12$ & 4 \\
\hline 5. & $\mathrm{E}$ & $2 / 12$ & $6 / 12$ & 4 \\
\hline 6. & $\mathrm{~F}$ & $2 / 12$ & $9 / 12$ & 7 \\
\hline 7. & $\mathrm{G}$ & $3 / 12$ & $12 / 12$ & 9 \\
\hline 8. & $\mathrm{H}$ & $2 / 12$ & $6 / 12$ & 4 \\
\hline 9. & $\mathrm{I}$ & $2 / 12$ & $6 / 12$ & 4 \\
\hline 10. & $\mathrm{~J}$ & $2 / 12$ & $7 / 12$ & 5 \\
\hline 11. & $\mathrm{~K}$ & $3 / 12$ & $12 / 12$ & 9 \\
\hline 12. & $\mathrm{~L}$ & $2 / 12$ & $9 / 12$ & 7 \\
\hline 13. & $\mathrm{M}$ & $4 / 12$ & $12 / 12$ & 8 \\
\hline 14. & $\mathrm{~N}$ & $2 / 12$ & $7 / 12$ & 5 \\
\hline 15. & $\mathrm{O}$ & $2 / 12$ & $8 / 12$ & 6 \\
\hline 16. & $\mathrm{P}$ & $1 / 12$ & $5 / 12$ & 4 \\
\hline 17. & $\mathrm{Q}$ & $2 / 12$ & $4 / 12$ & 2 \\
\hline 18. & $\mathrm{R}$ & $2 / 12$ & $4 / 12$ & 2 \\
\hline 19. & $\mathrm{~S}$ & $2 / 12$ & $8 / 12$ & 6 \\
\hline 20. & $\mathrm{~T}$ & $2 / 12$ & $7 / 12$ & 5 \\
\hline
\end{tabular}

Table 5 portrays the pupils' result on reading and writing screening for Literacy Intervention Programme (LBI). The score for construct 2 in March shows that $75 \%$ of the pupils only managed to associate sounds with the letters of the alphabet. In the beginning of the screening, the pupils still could not blend and segments phonemes into recognizable words thus made it difficult for them to read and get to the higher construct. After the implementation of Jolly Phonics Strategy, the pupils demonstrated much better result as there is increase in the construct in October as compared to March. Based on pupils' achievement in October, $70 \%$ of them were able to achieve construct 6 and above. These pupils are able to understand and used the language at phrase level in liner texts. Therefore, this result complements with the study by Koda (2005) highlighted that lower level verbal processing skills, such as phonological processing, which is the product of developing phonemic awareness, is important for the process of registering information in working memory in reading. In similar study, Yeung et al., (2013) found that synthetic phonics method of instruction had facilitated the acquisition of phonological awareness, expressive vocabulary, word reading, and word spelling among the ESL kindergarteners, aged 4 to 6 . This finding point out that Jolly Phonic had positive impact for struggler readers based on the students' scores in the post test.

\section{DISCUSSION AND IMPLICATION}

In this case study, Jolly phonics has been demonstrated to be an effective method of instruction whereby both teacher and student acquired the phonemic, phonics and meta-language skills necessary to be competent in English literacy. The study implies that not all phonics learning systems are equal or of the same quality. The type of phonics system utilized must include the 42 phonemes and systematic instruction, so that teachers may master the skills to teach English literacy to their students. Jolly phonics is highly recommended as an approach that can be adopted in Malaysian classroom. Its systematic and comprehensive phonemic and phonics instruction act as a compelling instrument for language acquisition for learners throughout Malaysia.

Despite the encouraging result, some limitation while conducting the research is time constraint. In order to boost up pupil's learning competence, the teacher should practice Jolly Phonics strategies as often as possible. Another limitation of this study is the lack of control group. Due to small amount of the participants involved in the research, more evidence is required to demonstrate conclusive findings for the study. By including more participants in the future, the study will be more comprehensive in regards of Jolly Phonics' ability to bring improvements to pupils' phonological awareness.

\section{CONCLUSION}

In conclusion, the Malaysia Ministry of Education (MOE) should consider implementing Jolly Phonics to teach English language in Malaysia. This study has shown that Jolly Phonics has the potential to be more effective in increasing the English literacy among young pupils. This is evident as more and more countries around the world are recognizing Jolly Phonics as the key instrument to teach both native and non-native speakers the English language. Therefore, a future large-scale pilot study to evaluate the effectiveness of Jolly Phonics in the country's institutions should be carried out over a year study period. The results from this study will replicate the findings that have been discovered about Jolly Phonics' ability to bring improvements especially to Malaysian English teaching and learning process.

\section{REFERENCES}

[1] Abdullah, N. Y., Kepol, N., \& Shari, M. (2014). Implementing the Teaching of Phonics in Malaysian Primary Schools. AJELP: The Asian 
Journal of English Language and Pedagogy, 2, 95-111. Retrieved from http://ojs.upsi.edu.my/index.php/AJELP/article/view/1103

[2] Adams, M.J., B.R. Foorman, I.Lundberg, \& T. Beeler (1998) Phonemic Awareness in Young Children: A Classroom Curriculum. Paul Brookes Publishing Co.

[3] Ding, J. (2015). A case study on the use of phonics instruction, implicit and explicit, to help low proficiency ESL learners at primary level to develop proficiency and enjoyment in English reading.

[4] Ferguson, N., Currie, L., Paul, M., \& Topping, K. (2011). The longitudinal impact of a comprehensive literacy intervention. Educational Research, 53 (3), 237-256.

[5] Gray, C., Ferguson, J., Behan, S., Dunbar, C., Dunn, J., \& Mitchell, D. (2007). Developing young readers through the linguistic phonics approach. International Journal of Early Years Education, 15(1), 15-33.

[6] Hall, K. (2006). How children learn to read and how phonics help. In M. Lewis\& S. Ellis, (Eds.). Phonics: Practice, research and policy. London: Paul Chapman Publishing.

[7] Kaminski, R. A. (2002). Dynamic indicators of basic early literacy skills: DIBELS. R. H. Good (Ed.). Dynamic Measurement Group.

[8] Kırkgöz, Y. (2008). Curriculum innovation in Turkish primary education. Asia-Pacific Journal of Teacher Education, 36(4), 309-322. doi.org/10.1080/13598660802376204

[9] Khairul Azhar Jamaludin, Norlidah Alias, Roselina Johari Mohd Khir, Dorothy DeWitt \& Husaina Banu Kenayathula (2015): The effectiveness of synthetic phonics in the development of early reading skills among struggling young ESL readers, School Effectiveness and School Improvement: An International Journal of Research, Policy and Practice, DOI: 10.1080/09243453.2015.1069749

[10] Koda, K. (2005). Insights into Second Language Reading. Cambridge: Cambridge University Press.

[11] Lloyd, S., Wernham, S., Jolly, C., \& Stephen, L. (1998). The phonics handbook. Chigwell, UK: Jolly Learning.

[12] Ministry of Education Malaysia (2011). The English Language Curriculum for Primary Schools. MOE Curriculum Development Centre.

[13] Morais, J.; Mousty, P. \& Kolinsky, R (1998). "Why and how phoneme awareness helps learning to read.” In C. Hulme and R. M. Joshi (Eds.), Reading and Spelling: Development and Disorders. Mahwah, NJ Lawrence Erlbaum, Asc., p. 127 - 152.

[14] O'Connor, R. E. \& Padeliadu, S. (2000) Blending versus whole word approaches in first grade remedial reading: short-term and delayed effects on reading and spelling words, Reading and Writing, 13, $159-182$.

[15] Torgesen, J.K. \& Mathes, P.G. (1998). "What Every Teacher Should Know About Phonological Awareness." Florida State University, Florida Department of Education.

[16] Snow, C. E., Burns, M. S., \& Griffin, P. (1998). Preventing reading difficulties in young children. Washington, DC: National Academy Press.

[17] Stanovich, K. E., \& Siegle, L.S. (1994). "Phenotypic performance profiles of children with reading disabilities: A regression-based test of the phonological-core variable-difference model." Journal Educational of Psychology, 86, p.24-53.

[18] Yeung, S. S. S., Siegel, L. S., \& Chan, C. K. K. (2013). Effects a phonological awareness program on English reading and spelling among of Hong Kong Chinese ESL children. Reading and Writing, 26, 681-704.

Yvonne Asong is a student at Universiti Kebangsaan Malaysia (UKM), pursuing her Master of Education in Teaching English as a Second Language (TESL). She obtained her degree also majoring in TESL from the Institute of Teacher Education (ITE) Malaysia, Batu Lintang Campus, Sarawak in 2015. She is currently teaching in a rural primary school in Julau, Sarawak, Malaysia. She had participated and won silver medal in the International Invention \& Innovative Competition 2018 in Kuala Lumpur, Malaysia.

Nur Ehsan Mohd Said is a lecturer at the Faculty of Education, Universiti Kebangsaan Malaysia (UKM), who pursuing his career in the academia in 2009. He obtained his PhD in English Language and Linguistics from the University of Sheffield, United Kingdom. His primary research interests lie in the areas of classroom research and intervention studies, differentiated module development, and English for specific purposes. 